\title{
The versatility of median sternotomy in general paediatric surgery
}

\author{
M Gopal, MB BS, MS (Gen Surg), MRCS, DCH; S-H Chung, MB BCh; C Westgarth-Taylor, MB BCh, BSc, FCS (Paed Surg); \\ R Fartacek, CCST (Austria and Europe); J Loveland, MB BCh, FCS, Cert Paed Surg
}

Department of Paediatric Surgery, Faculty of Health Sciences, University of the Witwatersrand, Johannesburg, South Africa

Corresponding author: J Loveland (loveland@wol.co.za)

Background. While common in cardiac surgery, median sternotomy (MS) is rarely required in general paediatric surgery. In the era of advancing endoscopic techniques, sternotomy is perceived as an extremely invasive incision, associated with prolonged postoperative recovery and significant morbidity.

Methods. We conducted a retrospective chart review of all children undergoing MS for non-cardiac indications between January 2007 and September 2012 and describe the pathology, number of ventilated days, duration of intensive care unit stay and analgesic requirements.

Results. Our experience over the past 6 years includes 14 children, aged between 8 months and 13 years. Indications for surgery included penetrating mediastinal trauma (1), anterior and posterior mediastinal masses (4), acquired tracheo-oesophageal fistulas secondary to button battery impaction (2), bronchial foreign bodies (2) and bilateral pulmonary metastases secondary to malignancy (5). The range of postoperative ventilation required was 0 - 34 days (median 1 day) and the range of duration of stay in the paediatric intensive care unit $1-39$ days (median 4 days). Postoperative analgesia was provided with intravenous or oral paracetamol with or without the addition of morphine. All the children tolerated the procedure well with no sternotomy-related complications on follow-up.

Conclusion. This review highlights the variety of conditions in which MS provides unrivalled access to the mediastinum and how well the procedure is tolerated by the paediatric patient, and emphasises the importance of sternotomy being within the armamentarium of access techniques of the general paediatric surgeon.

S Afr Med J 2013;103(10):732-735. DOI:10.7196/SAMJ.6769

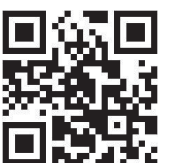

Median sternotomy (MS) is the most common incision made in cardiac surgery; however, it is rarely performed or required by general paediatric surgeons. Additionally, in the era of advancing endoscopic techniques, MS is perceived as an extremely invasive incision, associated with prolonged postoperative recovery and significant morbidity. Over the past 6 years, we have utilised MS in the management of 14 children. Although a relatively rare incision to make, the unrivalled access it provides and the variety of conditions in which we resorted to it made us feel that it was important to report our experience. We believe that this incision should be within the armamentarium of all general paediatric surgeons.

\section{Methods}

After institutional approval, we performed a retrospective chart review of all children who underwent MS as part of their surgical treatment in our unit from January 2007 to September 2012. Using a standard incision from the suprasternal notch to the xiphisternum, the sternum was divided with a pneumatic saw in older children and a Gigli wire in younger children. The sternotomy was closed with interrupted polydioxanone (PDS) sutures in all cases (Fig. 1). The indication for surgery, number of days on ventilation, duration of intensive care stay and analgesic requirements were documented.

\section{Results}

During the study period, MS was performed as part of the surgical treatment in 14 patients with ages ranging from 8 months to 13 years; of these 6 were male and 8 female (Table 1). All patients were admitted to the paediatric intensive care units (PICUs) at Chris Hani Baragwanath Academic Hospital and Charlotte Maxeke
Johannesburg Academic Hospital, Johannesburg, South Africa, after sternotomy. Pathology included penetrating mediastinal trauma (1), anterior and posterior mediastinal masses (4), acquired tracheooesophageal fistulas secondary to button battery impaction (2), bronchial foreign bodies (2) and bilateral pulmonary metastases secondary to malignancy (5). Nine of the 14 patients were extubated either immediately after the operation or in the PICU the next day. The number of days of ventilation ranged from 0 to 34 (median 1 day) and the number of actual days in the PICU from 1 to 39 days (median 4 days). Three patients had a prolonged PICU stay, not because of the surgical procedure itself but as a result of the underlying disease condition. Analgesic requirements in the PICU were limited to intravenous or oral paracetamol, with the addition of intravenous morphine if indicated (morphine was given to 8 of the 14 patients). Analgesia in the general wards was limited to intravenous or oral paracetamol.

To date 2 patients have died. The first presented with mediastinitis and died of systemic sepsis and multiple organ failure on the second postoperative day after delayed presentation with a tracheooesophageal fistula after button battery ingestion. The second patient had resection of pulmonary metastases from nephroblastoma, and despite a technically successful procedure died of metastatic disease during ongoing oncological management.

\section{Discussion}

Each pathological group will be discussed, specifically with regard to the benefits, potential complications and long-term effects of MS, as well as the role of less invasive approaches.

Trauma. The value of MS following penetrating precordial trauma is undisputed. There was only 1 case of penetrating chest trauma in 


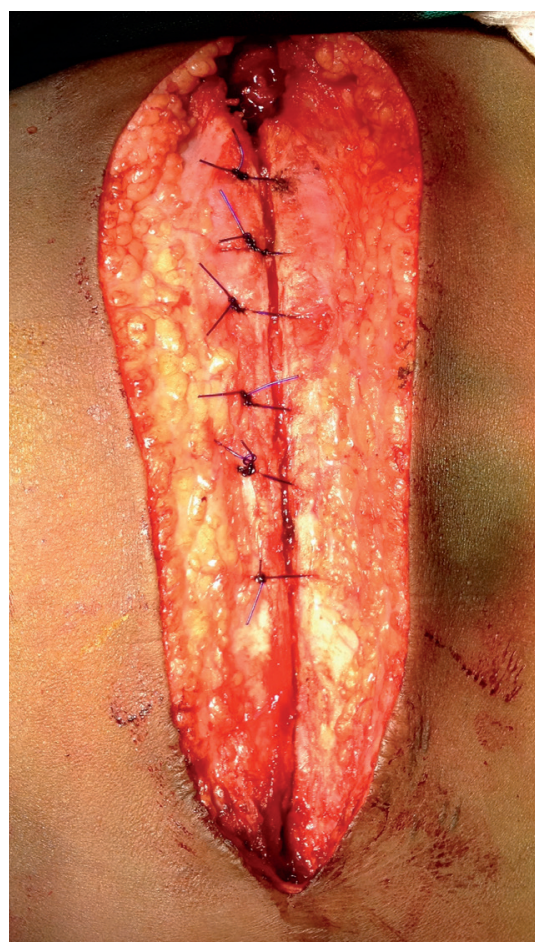

Fig. 1. The sternotomy was closed with interrupted polydioxanone sutures in all cases.

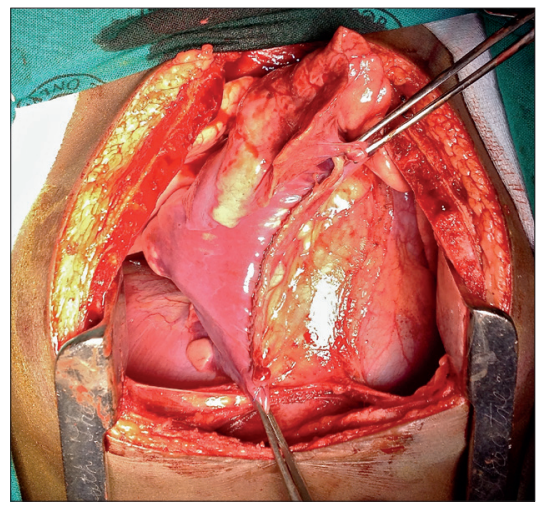

Fig. 2. Resection of a metastasis from the lower lobe of the right lung using a linear stapler.

this series, in a child who sustained numerous stab wounds to the abdomen and precordium, necessitating urgent exploration. Sternotomy and laparotomy revealed lacerations to the left atrium, segment 4 of the liver and the transverse colon. The atrial injury was repaired using pledgeted 5/0 polypropylene and the pericardial sac was incompletely closed and drained. Intrathoracic tracheal and proximal bronchial injuries are also ideally suited to repair via MS. ${ }^{[1,2]}$ We need to emphasise that sternotomy should not be used in the emergency room owing to the length time of required to achieve safe surgical exposure. If the patient presents in extremis, an anterolateral thoracotomy remains the recommended approach to achieve control and stabilise the patient. If necessary, this can subsequently be extended across the midline into a clamshell incision in theatre; alternatively, MS can be added.

Mediastinal lesions. There were 4 cases in this group, including a giant thymoma, a lymphatic malformation extending from the neck into the mediastinum, a teratoma and an oesophageal duplication cyst. Other mediastinal tumours that occur in children are lymphomas, leukaemic deposits and neuroblastoma with its pathological variants. The diagnosis of these conditions can often be made by less invasive methods, including serology, bone marrow aspiration and trephine biopsy. However, if a tissue diagnosis is deemed necessary, it can be achieved by thoracoscopy, mediastinoscopy or the Chamberlain procedure. ${ }^{[3]}$ If resection of the tumour is required, it can be performed safely via the MS approach. ${ }^{[4,5]}$ For mediastinal tumours that extend into a hemithorax, a lateral extension of the sternotomy into an intercostal space (T-shaped incision) will increase exposure, although we did not require this additional exposure in any of our cases. ${ }^{[6]}$ The main advantage of sternotomy is that it gives excellent exposure with good vascular control on the medial aspect of the tumour, as well as access to both hemithoraces. Mediastinal tumours can also often cause pre- or intraoperative airway problems. ${ }^{[7]}$ Sternotomy is advantageous in this situation, as it facilitates immediate access to the airway in the case of such problems, and extracorporeal membrane oxygenation can even be instituted in extreme circumstances. With regard to alternative approaches, while open thoracotomy is an option, there has been a reported death during attempted resection of a mediastinal tumour in a neonate via a thoracotomy ${ }^{[8]} \mathrm{A}$ recent series of 39 cases of mediastinal tumours in children included 12 lesions in the anterior mediastinum that were resected using thoracoscopic techniques. ${ }^{[9]}$ The final decision on which approach to take must be individualised and based on location and extent of the tumour, potential airway compromise, and availability of and experience with advanced thoracoscopic techniques.

Foreign bodies. In our series 4 children presented with impacted foreign bodies, 2 in the airway and 2 primarily in the oesophagus with subsequent erosion into the trachea. The first patient presented with a retained pin in the right main bronchus. There was delayed presentation complicated by a bronchopleural fistula. Initial treatment with an intercostal underwater drain and attempted bronchoscopic removal of the foreign body was unsuccessful owing to the presence of extensive granulation tissue surrounding the pin. After MS and selective ventilation of the left lung, the right main bronchus was opened and the foreign body removed, with repair of the bronchopleural fistula. A second child presented with a chronically obstructed left main bronchus with destruction of the entire left lung. Sternotomy provided excellent access to the hilar structures, including the left main bronchus. A left pneumonectomy was performed, and after division of the left main bronchus a completely occluding plastic pellet was found in the distal bronchus.

There were 2 cases of acquired tracheooesophageal fistula secondary to button battery impaction in the oesophagus. This complication is well recognised and was diagnosed by contrast swallow examination. ${ }^{[10]}$ The fistula was just below the level of the sternal notch in both children. While higher fistulas can be treated through cervical incisions alone, as for congenital H-type tracheo-oesophageal fistulas, in both our cases the fistulas were inaccessible through an isolated cervical approach; in both there was necrosis of the adjacent oesophagus and trachea with large oesophago-tracheal fistulas. MS allowed excellent exposure and mobilisation of both trachea and oesophagus, enabling proximal and distal control, segmental resection, and primary anastomosis of both organs.

Pulmonary metastases. Numerous paediatric solid tumours metastasise to the lungs. It has been shown that resection of these metastases will increase survival, especially in nephroblastoma, osteosarcoma and hepatoblastoma. ${ }^{[1,12]}$ Unilateral metastases can be resected via an ipsilateral thoracotomy or thoracoscopy. However, a recent study that analysed the use of sternotomy for bilateral disease found that preoperative computed tomography scan assessment of number of metastases matched the actual number found intraoperatively in only 13 of 16 cases. ${ }^{[13]}$ This study highlighted the importance of tactile assessment to increase the chance of finding and resecting metastatic deposits, particularly when compared with endoscopic techniques. The left lower lobe is the most difficult area to assess via the sternotomy approach. ${ }^{[13]}$ Our series includes 5 patients who presented with bilateral lung metastases, 3 of which were secondary to nephroblastoma and 1 each to embryonal sarcoma of the liver and osteosarcoma of the femur (Fig. 2). While we firmly believe that sternotomy offers the optimal approach for cases that present with bilateral metastases, we have used both 


\section{Table 1. Details of patients}

\begin{tabular}{|c|c|c|c|c|c|c|c|}
\hline $\begin{array}{l}\text { Patient } \\
\text { No. }\end{array}$ & Age/gender & Diagnosis & $\begin{array}{l}\text { Date of } \\
\text { surgery }\end{array}$ & Procedures & $\begin{array}{l}\mathrm{V}(\mathrm{S}) \\
\text { days }\end{array}$ & Analgesia & Outcome \\
\hline 1 & 5 years $/ \mathrm{M}$ & Stab heart & $10 / 7 / 07$ & Sternotomy & $1(4)$ & IV paracetamol & \\
\hline \multirow[t]{2}{*}{2} & 9 years $/ F$ & Lipothymoma & $9 / 3 / 09$ & Thoracoscopy and biopsy & & & \\
\hline & & & $12 / 3 / 09$ & Sternotomy and excision & $1(4)$ & IV paracetamol & \\
\hline 3 & 13 years/M & $\begin{array}{l}\text { Anterior mediastinal } \\
\text { teratoma }\end{array}$ & $26 / 3 / 09$ & Sternotomy and excision & $0(1)$ & IV paracetamol & \\
\hline 4 & 8 months/F & $\begin{array}{l}\text { Lymphatic malformation } \\
\text { of neck extending into } \\
\text { mediastinum }\end{array}$ & $1 / 7 / 10$ & Sternotomy and excision & $11(19)$ & IV paracetamol & \\
\hline \multirow[t]{2}{*}{5} & 8 months/M & $\begin{array}{l}\text { Upper oesophageal } \\
\text { duplication cyst }\end{array}$ & $22 / 5 / 12$ & Sternotomy and excision & $34(39)$ & $\begin{array}{l}\text { IV paracetamol } \\
\text { IV morphine }\end{array}$ & \\
\hline & & $\begin{array}{l}\text { Chylothorax } \\
\text { Subglottic stenosis }\end{array}$ & $28 / 5 / 12$ & $\begin{array}{l}\text { Thoracotomy } \\
\text { Bronchoscopy }\end{array}$ & & & \\
\hline 6 & 7 years $/ \mathrm{M}$ & Pin in right main bronchus & $26 / 8 / 09$ & Bronchoscopy and sternotomy & $1(4)$ & IV paracetamol & \\
\hline 7 & 3 years/F & $\begin{array}{l}\text { Plastic ball in left main } \\
\text { bronchus }\end{array}$ & $25 / 5 / 09$ & Sternotomy and pneumonectomy & $2(4)$ & IV paracetamol & \\
\hline \multirow[t]{3}{*}{8} & 2 years $/ F$ & $\begin{array}{l}\text { Button battery in } \\
\text { oesophagus with TOF }\end{array}$ & $2 / 12 / 11$ & $\begin{array}{l}\text { Oesophagoscopy and removal of } \\
\text { button battery }\end{array}$ & & & \\
\hline & & & $5 / 12 / 11$ & $\begin{array}{l}\text { Combined neck incision and } \\
\text { median sternotomy for repair of TOF }\end{array}$ & $23(29)$ & $\begin{array}{l}\text { IV paracetamol } \\
\text { IV morphine }\end{array}$ & \\
\hline & & & $17 / 12 / 11$ & $\begin{array}{l}\text { Sternotomy, gastrostomy and } \\
\text { oesophagostomy }\end{array}$ & & & \\
\hline \multirow[t]{2}{*}{9} & 1 year/F & $\begin{array}{l}\text { Button battery in } \\
\text { oesophagus with TOF }\end{array}$ & $17 / 4 / 12$ & $\begin{array}{l}\text { Oesophagoscopy and removal of } \\
\text { battery }\end{array}$ & & & \\
\hline & & & $18 / 4 / 12$ & $\begin{array}{l}\text { Combined neck incision and median } \\
\text { sternotomy for repair of TOF }\end{array}$ & $2(2)$ & $\begin{array}{l}\text { IV paracetamol } \\
\text { IV morphine }\end{array}$ & $\begin{array}{l}\text { Died on } \\
\text { POD } 2\end{array}$ \\
\hline \multirow[t]{2}{*}{10} & 5 years $/ \mathrm{M}$ & Nephroblastoma & $13 / 8 / 07$ & Left nephrectomy & & & Died in 2012 \\
\hline & & & $3 / 4 / 08$ & $\begin{array}{l}\text { Sternotomy and biopsy of bilateral } \\
\text { pulmonary metastasis }\end{array}$ & $0(1)$ & $\begin{array}{l}\text { IV paracetamol } \\
\text { IV morphine }\end{array}$ & \\
\hline \multirow[t]{2}{*}{11} & 2 years $/ M$ & Nephroblastoma & $1 / 10 / 07$ & Right nephrectomy & & & \\
\hline & & & $12 / 6 / 08$ & $\begin{array}{l}\text { Sternotomy and biopsy of bilateral } \\
\text { pulmonary metastasis }\end{array}$ & $0(1)$ & $\begin{array}{l}\text { IV paracetamol } \\
\text { IV morphine }\end{array}$ & \\
\hline 12 & 4 years/F & Nephroblastoma & $30 / 8 / 12$ & $\begin{array}{l}\text { Left nephrectomy } \\
\text { Sternotomy and excision of } \\
\text { pulmonary metastasis }\end{array}$ & $1(4)$ & $\begin{array}{l}\text { Oral paracetamol } \\
\text { IV morphine }\end{array}$ & \\
\hline \multirow[t]{2}{*}{13} & 7 years $/ F$ & Osteosarcoma right femur & $12 / 4 / 11$ & Above-knee amputation & & & \\
\hline & & & $17 / 10 / 11$ & $\begin{array}{l}\text { Sternotomy and excision of bilateral } \\
\text { pulmonary metastases }\end{array}$ & $0(4)$ & $\begin{array}{l}\text { IV paracetamol } \\
\text { IV morphine }\end{array}$ & \\
\hline \multirow[t]{2}{*}{14} & 5 years $/ F$ & Embryonal sarcoma of liver & $20 / 9 / 07$ & Right hepatectomy & & & \\
\hline & & & $21 / 11 / 07$ & $\begin{array}{l}\text { Sternotomy and excision of bilateral } \\
\text { pulmonary metastases }\end{array}$ & $1(3)$ & $\begin{array}{l}\text { IV paracetamol } \\
\text { IV morphine }\end{array}$ & \\
\hline
\end{tabular}

thoracotomy and thoracoscopy for other cases, depending on their mode of, and distribution at, presentation.

The risk of mediastinitis following MS in children is approximately $1 \%{ }^{[14]}$ Unsurprisingly, most large series describing outcomes after sternotomy are from cardiothoracic units. In one of the largest series documenting the risk factors for developing postoperative mediastinitis in children, Kagen et al. found that only the presence of a genetic syndrome, an American Society of Anesthesiologists score of $>3$, and the presence of intracardiac pacing wires for $>3$ days were statistically significant. ${ }^{[15]}$ None of the children in our series developed mediastinitis, and in none were mediastinal drains left in situ.

Postoperative recovery in all our patients was smooth, with an average duration of ventilation of 1 day (range 0 - 34 days) and 
average PICU stay of 4 days (range 1 - 39 days). We were not able to find any studies comparing pain scores and recovery after sternotomy as opposed to thoracotomy or laparotomy in children. However, a study comparing mini-sternotomy with full sternotomy in children did not reveal any difference in pain scores or recovery. ${ }^{[16]}$ The authors postulated that the good tolerance of MS in children was due to the cartilaginous nature of the sternum, and the facts that sternal spreading utilises the mechanics of normal rib excursion, and that no muscles are spread or divided. Our subjective opinion is that the procedure is very well tolerated, and this is complemented by the exceptional exposure it provides.

Interrupted PDS sutures were used to close the sternotomy in all our cases. In a review of 264 sternotomies for cardiac surgery closed in this manner, the authors reported a $1.5 \%$ incidence of sternal infection, dehiscence or mediastinitis. ${ }^{[17]}$ We did not have to perform a repeat sternotomy in any of the children in our series, but review of 164 repeat sternotomies in children revealed a $5 \%$ incidence of injury during re-exploration and recommended strategies to avoid this. ${ }^{[18]}$ No child in our series developed chylothorax as a complication of the sternotomy. In a study comparing the incidence of postoperative chylothorax in children treated by MS or lateral thoracotomy for the correction of congenital cardiac abnormalities, both groups had an equal incidence. ${ }^{[19]}$ The thoracotomy group had a longer latency period before the onset of chylothorax, but in both groups the chylothorax could be managed by medical treatment alone. Finally, it has been well documented that anterolateral thoracotomies in infants can lead to breast and pectoral muscle maldevelopment. ${ }^{[20]}$ Similarly it has been shown that children who have MS for correction of congenital cardiac anomalies have a 10 times higher risk of developing scoliosis. ${ }^{[21]}$ Children undergoing surgery for cyanotic heart disease had the highest risk. No association was noted between risk of scoliosis and age at surgery, number of procedures, gender or heart size.

\section{Conclusion}

This review highlights the versatility of MS for the management of various conditions in children. It emphasises the excellent access it can provide and how well it is tolerated with respect to analgesic requirements and ventilation. In today's world of advancing minimal access techniques, knowledge of this maximal access approach is essential for the general paediatric surgeon.

\section{References}

1. Setty SP, Linden BC, Herrington C, McGonigal M. Pediatric tracheal disruption repaired via median sternotomy. J Trauma 2008;64(2):493-495. [http://dx.doi.org/10.1097/01.ta.0000222640.52306.4c

2. Beale P, Bowley DM, Loveland J, et al. Delayed repair of bronchial avulsion in a child through a median sternotomy. J Trauma 2005;58(3):617-619. [http://dx.doi.org/10.1097/01. TA.0000071845.16204.16

3. Glick RD, Pearse I, Trippett T, Saenz NC, Ginsberg RJ, La Quaglia MP. Diagnosis of mediastinal masses in pediatric patients using mediastinoscopy and the Chamberlain procedure. J Pediatr Surg 1999;34(4):559-564. [http://dx.doi.org/10.1016/S0022-3469(99)90073-8]

4. Lakhoo K, Boyle M, Drake DP. Mediastinal teratomas: A review of 15 pediatric cases. J Pediatr Surg 1993;28(9):1161-1164. [http://dx.doi.org/10.1016/0022-3468(93)90155-E]

5. Koga H, Yamataka A, Kobayashi H, Miyamoto H, Lane GJ, Miyano T. Median sternotomy provides excellent exposure for excising anterior mediastinal tumors in children. Pediatr Surg Int provides excellent exposure for excising anterior mediastinal tumor in

6. Ito T, Nagaya M. New operative approach for large mediastinal teratoma in children - complete median sternotomy with lateral incision. Eur J Pediatr Surg 1983;38(6):425-428. [http://dx.doi. $\mathrm{org} / 10.1055 / \mathrm{s}-2008-1060026]$

7. Garey CL, Laituri C, Valusek P, St Peter SD, Snyder CL. Management of anterior mediastinal masses in children. Eur J Pediatr Surg 2011;21(5):310-313. [http://dx.doi.org/10.1055/s-0031-1279745]

8. Seibert JJ, Marvin WJ, Rose EF, Schieken RM. Mediastinal teratoma: A rare cause of severe respiratory distress in the newborn. J Pediatr Surg 1976;11(2):253-255. [http://dx.doi.org/10.1016/0022-3468 (76)90298-0]

9. Partrick DA, Rothenberg SS. Thoracoscopic resection of mediastinal masses in infants and children: An evaluation of technique and results. J Pediatr Surg 2001;36(8):1165-1167. [http://dx.doi. org/10/1053/JPSU.2001.25740]

10. Litovitz T, Whitaker N, Clark L, White NC, Marsolek M. Emerging battery-ingestion hazard: Clinical implications. Pediatrics 2010;125(6):1168-1177. [http://dx.doi.org/10.1542/ peds.2009-3037]

11. La Quaglia MP. The surgical management of metastases in pediatric cancer. Semin Pediatr Surg 1993;2(1):75-82.

12. Fuchs J, Seitz G, Handgretinger R, Shaffer J, Warmann S. Surgical treatment of lung metastasis in patients with embryonal pediatric solid tumors: An update. Semin Pediatr Surg 2012;21(1):79-87. [http://dx.doi.org/10.1053/j.sempedsurg.2011.10.008]

13. Fuchs J, Seitz G, Ellerkamp V, et al. Analysis of sternotomy as treatment option for the resection of bilateral pulmonary metastases in pediatric solid tumors. Surg Oncol 2008;17(4):323-330. [http:// dx.doi.org/10.1016/j.suronc.2008.05.004]

14. Long CB, Shah SS, Lautenbach E, et al. Postoperative mediastinitis in children: Epidemiology, microbiology and risk factors for Gram-negative pathogens. Pediatr Infect Dis J 2005;24(4):315-319. [http://dx.doi.org/10.1097/01.inf.0000157205.31624.ed]

15. Kagen J, Lautenbach E, Bilker WB, et al. Risk factors for mediastinitis following median sternotomy in children. Pediatr Infect Dis J 2007;26(7):613-618. [http://dx.doi.org/10.1097/INF.0b013e31806166bb]

16. Laussen PC, Bichell DP, McGowan FX, Zurakowski D, DeMaso DR, del Nido PJ. Postoperative recovery in children after minimum versus full-length sternotomy. Ann Thorac Surg 2000;69(2):591596.

17. Keçeligil HT, Kolbakir F, Akar H, Konuralp C, Demir Z, Demirağ MK. Sternal closure with resorbable synthetic loop suture material in children. J Pediatr Surg 2000;35(9):1309-1311. [http://dx.doi. org/10.1053/jpsu. 2000.9311]

18. DeLeon SY, LoCicero III J, Ilbawi MN, Idriss FS. Repeat median sternotomy in pediatrics: Experience in 164 consecutive cases. Ann Thorac Surg 1986;41(2):184-188. [http://dx.doi.org/10.1016/S0003-4975 (10) $62665-3$

19. Wu J-M, Yao C-T, Kan C-D, Yeh C-N, Yang Y-R, Wang J-N. Postoperative chylothorax: Differences between patients who received median sternotomy or lateral thoracotomy for congenital heart disease. J Card Surg 2006;21(3):249-253. [http://dx.doi.org/10.1111/j.1540-8191.2006.00225x]

20. Cherup LL, Siewers RD, Futrell JW. Breast and pectoral muscle maldevelopment after anterolateral and posterolateral thoracotomies in children. Ann Thorac Surg 1986;41(5):492-497. [http://dx.doi, org/10.1016/ S0003-4975 (10)63025-1]

21. Herrera-Soto JA, Vander Have KL, Barry-Lane P, Myers JL. Retrospective study on the development of spinal deformities following sternotomy for congenital heart disease. Spine 2007;32(18):1998-2004. [http://dx.doi.org/10.1097/BRS.0b013e318131b225]

Accepted 8 May 2013 